\begin{tabular}{|l|l|l|l|l|}
\hline Submission & Review Process & Revised & Accepted & Published \\
\hline $05-11-2019$ & $05-11$ s/d 05-12-2019 & $30-12-2019$ & $30-12-2019$ & $31-12-2019$ \\
\hline
\end{tabular}

Jurnal Studi Sosial dan Politik, Vol. 3, No. 2, December 2019 (146-155)

ISSN 25978756

e ISSN 25978764

Jurnal Studi Sosial dan Politik Published by: FISIP Universitas Islam Negeri Raden Fatah Palembang

\title{
Malay Muslims Patani Insurgency Pattern in the Post-Revolution 1932
}

\author{
Ahmad Syukri \\ Fakultas Ilmu Sosial dan Ilmu Politik Universitas Islam Negeri Raden Fatah \\ Email: ahmadsyukri@ radenfatah.ac.id
}

\begin{abstract}
Malay Muslim Patani is a majority resident in southern Thailand. They have a long history of the insurgency against the Thai regime lasted since the 18th century. This literature study analyzes the context of Malay Muslim Patani insurgency pattern against the Thai regime in the post-revolution 1932. In The Post-revolution 1932, the Malay Muslim Patani insurgency pattern was likely to strengthen in response to the policies of the Thai regime repressive to insurgency issues and strict assimilation policies that demanded an all-ethnic identity in Thailand to be the True ethnic Thai identity. For the last decade, the concept of Islam as the political identity has increasingly made it a determination to establish the Malay identity of Patani Islam as the basis of the insurgency movement. To realize the sustainable peace in Malay Muslim Patani area can be through a religious approach.
\end{abstract}

Keywords : Malay Muslim Patani, Insurgency, Southern Thailand, Political Identity

\begin{abstract}
Abstrak
Melayu Islam Patani adalah penduduk mayoritas di wilayah Selatan Thailand. Mereka memiliki sejarah panjang insurjensi terhadap rezim Thai dari sejak abad ke-18. Dalam studi literatur ini menganalisis pola insurjensi Melayu Islam Patani terhadap rezim Thai pasca revolusi tahun 1932. Pasca revolusi tahun 1932, pola insurjensi Melayu Islam Patani cenderung menguat dalam menanggapi kebijakan represif rezim Thai, dimana kebijakan asimilasinya yang menuntut identitas semua etnis di Thailand menjadi identitas Thai seutuhnya. Dalam satu dekade terakhir, konsep Islam sebagai identitas politik yang menjadi identitas Melayu Patani Islam sebagai dasar gerakan insurjensi. Melalui pendekatan keagamaan dapat diupayakan dalam mewujudkan perdamaian yang berkelanjutan di daerah Melayu Islam Patani
\end{abstract}

Keywords: Melayu Islam Patani, Insurjensi, Selatan Thailand, Identitas Politik 


\section{INTRODUCTION}

The most significant number of Muslims in Thailand was derived from ethnic Malays. Malay Muslims in Thailand not only live in the southern region, exactly three provinces of Pattani, Yala, and Narathiwat, but also live in the Satun, Songkhla, Trang, Krabi, and Phuket. In the historical records, once present the Kingdom of Patani as the ruler of the Malay Islamic Kingdom of Patani. The king of Siam finally conquered the Kingdom of Patani in 1786 A.D. After the Anglo-Siamese treaty 1904 and 1909, it is increasingly apparent that the Malay region Patani became part Integral to the domination of the Thai Buddhist kingdom is not a Malay kingdom anymore (Forbes, 1982).

The Thai government took a policy by dividing Patani's Malay Muslim territories into seven provinces, in a centralized administrative system. In each of these lands, a king or Chao Muang under the supervision of Songkhla. With this change, the Malay Islamic kingdom ended in Patani. The Malay territory of Patani was only one of the newly formed lands that entered the power of the Siamese regime (Bonney, 1971)

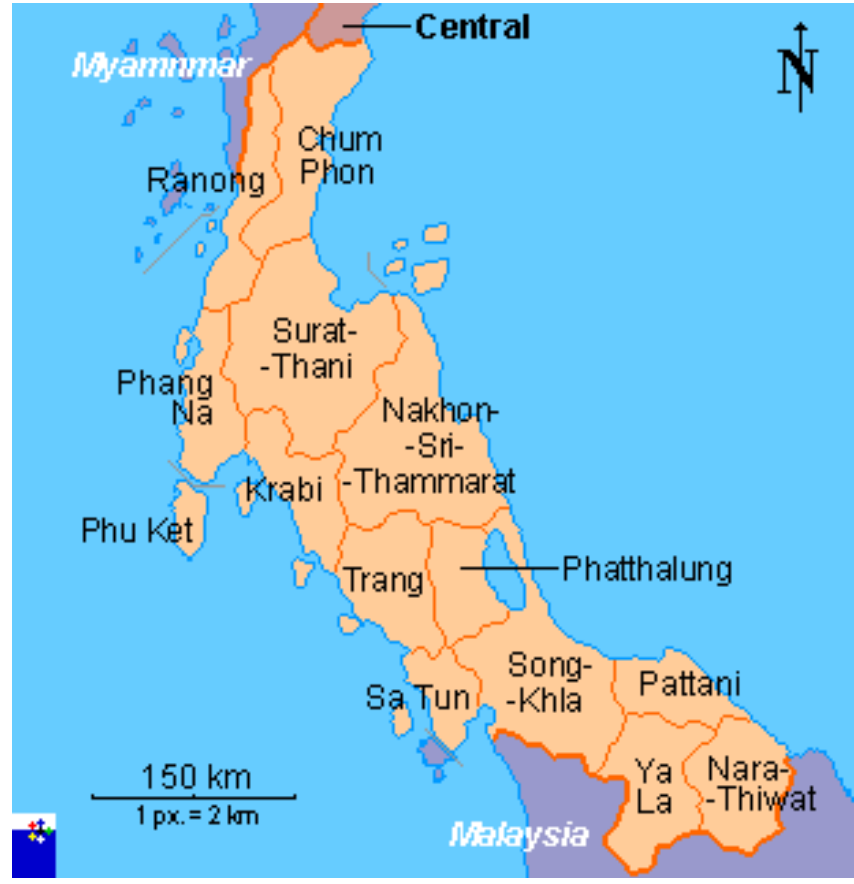

Southern Thailand

Source : https://flagspot.net/flags/th(s.html

The Thai regime implemented a policy of assimilation of Malay Muslim residents in the south to Muslim Thai, after World War II. This policy was a model of the Patani Malay insurgency movement in the early 20th century (Gross, 2007). The change of the Thai governance system, from the type of absolute monarchy to the constitutional monarchy, began in the revolution in June 1932, with the People's Party (Khana Ratsadon) as the pioneer of its movements. A coalition party consisted of bureaucrats, princes, and military officers. The revolution spawned a democratic system in Thailand and was legally formally written in the Royal Constitution of Siam 1932 (Preechasinlapakun, 2013). 
The policy process of Thai identity assimilation began on a high level during the regime of Prime Minister Phibun Songkhram, an ultranationalist who was also a military officer involved in the 1932 revolution. Phibun Songkhram ruled in 1938. Phibun Songkhram adopted a policy of assimilation following the system of the previous regime, which forced the various minority cultures in Thailand, becoming the mono-ethnic Thai as part of the national identity (Croissant, 2007).

Phibun Songkhram soon launched a campaign to eliminate Malay-Muslim cultural identity for Thai nationalism. The degradation of Muslim Malay identity in all fields, including education, language, clothing, and religious practices. Over the last decade, the intensity of the violent separatist movement is increasingly growing in the southern provinces of Thailand. The Malay historical background of Patani and policy of government assimilation, forming Patani's Malay identity with Islam as the source of its primary resistance. In 1947, it appeared in the Malay region of Patani a separatist movement to fight for the independence of Patani with the title Malay Movement of Patani Raya (Malay Grand League Patani). Then it was emerged Barisan Nasional Liberation Patani (BNPP) in 1959, since then, it began to clash between the parties who wanted the independence of Patani and security forces in the province of southern Thailand (Gross, 2007).

The intensity of conflict between Malay Muslim rebels Patani and Thai security forces decreased slightly during the 1960s and 1970s. During the reign of Prem Tinsulanonda became Prime Minister in March 1980, the government supported the Cultural Rights and Freedom of Malay Muslims, offering the amnesty for the rebels that were all done for the plan of economic development for the southern Thailand region (Croissant, 2007).

The transition to a better democracy in Thailand offers the opportunity for Malay Muslims to be active in political participation, including political parties, such as the Democratic Party. Around the year of 1990, the democratic government of Prime Minister Chuan Leekpai (Democratic Party) formulated a national security policy for the province of the border in the south, with a model of development approach as security (Gross, 2007)

The Southern border area also conducted security cooperation between the Government of Thailand and Malaysia-which in the past seemed to close the eyes on the activities of Malay Patani insurgency in their region. This development contributed significantly to the decrease in the level of Malay Muslim insurgency Patani (Croissant, 2007).

The pockets of resistance remained, but most observers agreed that the rebellion had been shrinking and relatively quiet in the late 1990s. However, in the past few months, the first ten days of August 2016, the systematic attack of 50 of the bombs in the border province in southern Thailand. The indication of violence is closely related to the implementation of the referendum on August 7, 2016. The insurgent also wrote the anti-constitutional graffiti in 18 locations to influence public opinion in the south to oppose the Constitution (Engvall, 2016).

Based on the background of the problem, the authors attempted to analyze the context of the Malay Muslim Insurgency pattern against the Thai regime ih the post-revolution 1932.

\section{RESEARCH METHOD}

This literature study is a search for texts related to research topics. The literature is emphasized on the results of research and books discussing the Patani Malay community in Thailand. Besides, there are also readings and observations of various reference sources related to the topic. Data were 
analyzed by comparing between each text and then by linking it to the reality of the research problem. The results then became a conclusion that later became an essential result in this study.

\section{RESULTS AND DISCUSSION}

\section{Background on the Emergence of Insurgency Issues in Malay Region patani.}

In the History Book of Malay Kingdom Patani (SKMP), written by Ibrahim Syukri- an original Patani, who understands the local traditions and culture of Patani Malay. The idea of Malay nationalism influences SKMP. SKMP was published in the late 1940's, not in Patani but Pasir Putih, Kelantan, Malaysia. The book is contrary to the Thai regime's stance on many political issues concerning Malay Patani (Syukri, 1985)

Another point of view regarding the background of insurgency in southern Thailand. The role of the domestic Islam of Thailand constrained and hindered in many ways, as the Thai government dominated by Buddhist cosmology. Especially during the intensive period "Build Nation " From 1902 - the year 1957, the Thai government aggressively promotes trust "Buddhism, " "King, " and "Nation," and anyone who does not apply these same values not considered as part of a valid Thai citizen (Pitsuwan, 1985).

Conversely, Patani Muslims who did not apply these new norms often viewed with suspicion and humiliation. They were even identified or branded as separatism that threatens the survival of national development. For the Patani region, this cultural identity was forced to be enforced by the Thai government. This threat was a focal point for disagreements and resilience in Patani. Some Malay Muslim requested in the southern Thailand province to the Thai regime gave them the right to identity of Malay culture and their Islamic beliefs as they had practiced for generations (Pitsuwan, 1985).

Thai Government's efforts to integrate Thai identity as a national identity are the same as the cultural breakup of many Malay Muslim perspectives. In many ways, this threat of cultural disintegrating has triggered a reaction that is rooted in fear and resistance and has led to Muslim Patani to perform harder results.

In the studies of the Malays in the Patani region in the 1950s, saw Patani Malays trapped among the Thai regime's policy on education and cultural assimilation on one side and Malay separatism as a form of Sentiments on the other hand (Fraser, 1966). Unlike the Malays in other peninsular countries, Patani Melayu maintains the traditional power source of their sultan, as the Sultanate of Patani has been abolished by the Siamese regime in the early second century Twenty. With the loss of the Sultanate as a marker of the Malay communal identity Patani, they then took the religion as a substitute for the previously prevailing collective identity (Jory, 2007)

Modern Thai state has always been ambivalent in its policy towards the southern part of Thailand. As is Christian, Islam is recognized, and as a religious minority, and Buddhism is never officially designated as a state religion. Remained in the concept of the Thai regime's power when the Triad ' nation, religion, and King ' was involved, it was clear that Buddhism was a reference religion. All school books tend to articulate morals and ethics in the context of Buddhism. Muslim children can only learn about Islam from the Madrasah.

At a further level, the Muslim minority also faces the question of whether they are really ' Thai.' At the time of King Chulalongkorn, the term ' Muslim Thai ' began to popularize. It is presumably allowed them to remain ' Thai ' as well as ' Muslims ' although this was a matter of 
their Malay ethnic role. In the 1930s and 1940 's the Thai regime with cultural assimilation policy increasingly aggressive, limiting the use of Malay customary clothing and Malay language. Of course, this policy was fought by the Malays, who lived in the southern part of Thailand (Ricklefs et al., 2013).

The concept of 'nation' (chat) entered into force during Chulalongkorn's reign, when he sought to build loyalty among his people with diverse ethnic groups. To minimize racial gaps and introduce the idea of the monarchy of a 'Thai' nation, the term 'Orang Lao' transformed into a northeastern Thai, 'Orang Melayu' changed 'Thai Muslims' and so on. 'Triad' of the nation, religion and King' is a base of Thai nationalism, which more clearly and consistently articulated during the successor of Chulalongkorn, Vajiravudh (reigned 1910-1925) though-the latter has existed since the end of the 19th century (Ricklefs et al., 2013).

The post-World War II period, people living in the southern provinces of Thailand, demanded a separate regional government and the Islamic court system in addition to the official Malay language use at the local level and throughout the system Constitutional state in a broader context. Some voices demanded Patani be independent or parted and then join Malaysia. The military government, who took over power at the end of 1947, rejected most of these demands and was cracking down on the strict resistance in this area. Then, it was born a separatist movement that lived today with a variety of different names (Gross, 2007).

In 1960 the Thai government used a combination of military repression and ' soft power ' which was the increase in the presence of the royal family in the south after the construction of the palace in Narathiwat province. During Prem's reign, the situation was relatively stable, but the potential for conflict was not eliminated. However, throughout 1950-an, the primary concern of the Thai government in the context of integration is not the ' Southern Muslims ' but the Chinese community. Chinese is a community that is ethnically stronger than ethnic Malays (Ricklefs et al., 2013).

To some extent, the political articulation of the Malay ethnic consciousness in Patani can as a response to the economic sub-ordinations, culture, and politics of Muslim society as a result of Internal colonization. In this opinion, Thailand is a paradigmatic case of Internal colonization, where the economic gap very far in between central (Bangkok) and rural hinterland has resulted in economic retardation in the south (Croissant, 2007).

\section{Patani Malay Muslim insurgency post-revolution 1932}

The Siamese revolution that occurred in June 1932 was a bloodless coup conducted by young nationalist groups, military leadership, and civilian people. They did not fight the king as a symbol of the state of Thailand but against Conservative government ministers. Their goal is to turn the traditional absolute monarchy into a limited constitutional monarchy (Gross, 2007).

The revolution also finally brought the country's name change to Thailand in 1939, looking at all Thai citizens to have fully participated in the institution and culture of Thai people. Although Thailand's new leader of nationalism policy is almost entirely secular, Thai cultural cosmology is a Theravada Buddhist cosmology. This condition makes Malay Muslims Patani feel more marginalized in this new regime (LePoer, 1989).

During World War II, Japan invaded Southeast Asia at the end of 1941, taking over French Indochina, the Philippines, the Malay Peninsula, and the Dutch East Indies in the early 1942 years. The Thai ultra-nationalist regime led by Phibun Songkhram, allied with Japan and allowed Japan to enter the Malay Peninsula from the north in 1941 at the beach near Pattani (Gross, 2007). 
As a gift for the cooperation, Thailand received mastery from Japan during the war that was part of the territory in Laos, Cambodia, and Burma as well as four Malay regions, namely the states of Kelantan, Terengganu, Kedah, and Perlis. Most Malays during World War 2, collaborated with Japan for independence from the United Kingdom or the Netherlands. Much of Pattani Malays collaborated with the British against the Thai regime.

The leader of this movement was Tengku Mahmud Mahfdeen, the second son of Patani's last Sultan, Tengku Abdul Kadir, who had been exiled by the Thai government. He played an essential role in recruiting Malay volunteers with the power of 136 personnel in guerrilla warfare activities in Malaya to fight Japan (Gross, 2007).

Tengku Mahmud hoped that Britain's success in the war would result in the release of Patani from the Thai government. At the beginning of November 1945, shortly after the end of World War 2, seven prominent members of Malay ruling elite Patani filed a formal petition to London. They were requesting that the British government might have right to let go of our country and ourselves from the pressures of Siam, because we do not want to stay longer under the Siamese rule (Gross, 2007).

It was probably the most appropriate time for Malay Muslim Patani to realize their wishes separating themselves from Thailand. The British government considered the proposal seriously; even some members of the British government gave a positive response as a form of punish Thailand for his attitude that helped Japan in the war. But in the end, the proposal was raw without any clarity.

The change of government in Thailand in 1944, where new leaders can gradually reject the old regime agreement with Japan, even quietly gives free access to Allied agents operating in Thailand. Thus, Thailand has effectively turned the side during the war and could claim it was no longer a hostile force with the allies shown at the beginning of the War.

In January 1946, Britain and Thailand had signed a post-war treaty in which the latter approved the return of Kelantan, Terengganu, Kedah, and Perlis, as well as the Burmese section to England (Gross, 2007). Furthermore, the direct role of the United States, which in the final stages of World War II began to see Thailand as the key to the strategic importance of Western parties in south east Asia to block the communists in the north.

A few years later, in the governance of Thailand, precisely in 1960, the government carried out strict supervision of Madrasah in the Malay region of Patani. All boarding schools are registered with the Ministry of Education and add a secular curriculum, although there is no prohibition on the use of Malay language as instruction language, the use of the Thai style as an additional language in all schools in Malay region Patani. The enrolled schools are entitled to receive state funds and are subject to state inspections. It also includes the obligation to provide a list of teachers and student names. Unlisted Madrasah is considered illegal. As a result, 150 madrasahs closed from the estimated 355 schools that existed in 1971 — in the year 2004, allegedly residing 127 registered Madrasah still operating in the Malay region in southern Thailand (Madmarn, 1999).

The Madrasah system became the primary means used by Malay living in the south, to preserve and disseminate the teachings of Islam and Malay culture. On the other hand, since the 1960-an emerged a pattern of the Malay militant Patani agenda as a struggle to preserve Malay heritage in different ways in the southern region of Thailand, whose goal is apparent towards the Malay separatism model insurgency. The group includes BRN (National Revolution Line), GMIP (Pattani Islamic Mujahidin Movement), and PULO (Pattani United Liberation Organization). BNP $=\mathrm{BIP}-$ an umbrella organization whose movement of political coordination is slightly better than 
the group Separatist - believed to have indirect military operations in the southern regions of Thailand. Three factions left, New PULO is believed to be the smallest. GMIP may have a full area of activity, but the largest of the three main camps inevitably is BRN (Gross, 2007).

The separatist groups in South Thailand have recently done a method of struggle with a low intensity of risk and more sophisticated tactics. These actions include combustion, bombing, military attacks, and attacks on state officials, law enforcement personnel, local government officials, teachers, and Buddhist monks (Croissant, 2007).

The use of suicide bomb methods as a choice weapon of Islamic fighters since 1980, not so widespread. Since the year 2004, militants have also adopted new bombing tactics. They have focused on government and private buildings, Royal Thai Police members, and other representatives of the central government. Motorcycle bombs have been a liked method in this attack. While before mid-2004, insurgents were focusing on Buddhists, the targeting gradually shifted towards civilian security personnel (Croissant, 2007).

Table of Separatist Groups In Southern Thailand

\begin{tabular}{|c|c|c|}
\hline Organization & $\begin{array}{c}\text { Established } \\
\text { in }\end{array}$ & Characteristics \\
\hline $\begin{array}{l}\text { BRN (Barisan Revolusi } \\
\text { Nasional) }\end{array}$ & 1960 & $\begin{array}{l}\text { Separate in three wings: } 1 \text {. BRN Congress, the } \\
\text { main military arm, } 2 \text {. BRN coordinates focus on } \\
\text { political agitation and urban sabotage; } 3 \text {. BRN } \\
\text { scholars, as a most significant and most organized } \\
\text { faction, coordinating the following between } \\
\text { Islamic scholars }\end{array}$ \\
\hline $\begin{array}{l}\text { GMIP (Gerakan } \\
\text { Mujahideen } \\
\text { Islam Pattani) }\end{array}$ & 1995 & $\begin{array}{l}\text { The Afghan War veterans formed it near the } \\
\text { Association for the KMM (Malay mujahidin } \\
\text { Group) in Malaysia. }\end{array}$ \\
\hline $\begin{array}{l}\text { PULO (Pattani United } \\
\text { Liberation Organisation) }\end{array}$ & 1968 & $\begin{array}{l}\text { Active in guerrilla operations until the early } \\
\text { 1990s; Secular organizations have no military } \\
\text { ability. }\end{array}$ \\
\hline New PULO & 1995 & $\begin{array}{l}\text { It was divided as a faction of disagreements from } \\
\text { PULO in } 1995 \text { but formed a tactical alliance with } \\
\text { PULO two years later. }\end{array}$ \\
\hline $\begin{array}{l}\text { BNPP=BIPP }(\text { Barisan } \\
\text { Nasional Pembebasan } \\
\text { Pattani-Pattani } \\
\text { =Barisan Islam Pembebasan } \\
\text { Pattani-Pattani }\end{array}$ & 1963 & $\begin{array}{l}\text { Received support from traditional nobility as well } \\
\text { as from the religious elite; The goal is not only } \\
\text { the autonomy or integration of Patani with } \\
\text { Malaysia but the full independence and } \\
\text { establishment of an Islamic State, Darul Islam. }\end{array}$ \\
\hline $\begin{array}{l}\text { Bersatu (Barisan } \\
\text { Kemerdekaan } \\
\text { Pattani) }\end{array}$ & $1989 / 97$ & $\begin{array}{l}\text { It is established in 1989, the revival in } 1997 \text { as an } \\
\text { umbrella organization for the loose political } \\
\text { coordination between BRN, PULO, New PULO, } \\
\text { GMIP. }\end{array}$ \\
\hline
\end{tabular}

Source : (Croissant, 2007) 
While there is no evidence of a coordinated strategy between the various separatist faction groups in the southern regions of Thailand, but the mass-based separatist movement is well organized. Along with the increased outrage of the Malay Muslim community against the Thai regime, it became an excellent opportunity to recruit new members of the separatist group in the future. It is undeniable that there is a tendency for criminal action to be performed by secessionist groups. They seem to operate in a gray zone, by committing criminals on one side and ethnic or religious consciousness on the other. There are several persons involved as drug dealers (Croissant, 2007).

External group involvement from outside Malay region Patani, such as Al Qaeda and Jemaah Islamiyah in Thailand, can only provide training facilities, funds, motivation, and encouragement to Muslim rebels in southern Thailand (Liow, 2004). No involvement of Al-Qaeda or congregation Islamiyah has found in the form of active personal participation.

If there is an appraisal that says that the Malay Muslim separatist group Patani in southern Thailand as subordinate to transnational terrorist groups, it was a rash and very premature judgment. Despite evidence of relief for insurgents from South Asia, and some interconnectedness between insurgents and the Malaysian Islamic Party (PAS) in Malaysia, no clear and decisive evidence shows direct involvement of The external groups in Malay insurgency Patani (Croissant, 2007). In the period of conflict from 2004 until the year 2014. In the early years of violence, four years from January 2004 to December 2007, riots escalated considerably increased in temperature. Some well-coordinated attacks characterize some violent incidents. In June 2006, rebel parties were performing simultaneous attacks at 54 places in the three southern terminus provinces, most of which used self-modified explosives. In August 2006, disruption occurred in more than 122 locations in the south of tip provinces at the same time, ranging from bombing, combustion, tire burning. In September 2006, housing bombings and tourist areas in 7 places in the city of Hat Yai, the capital of Songkla province with a death toll of 5 people and more than 60 injured people (Jitpiromsri, 2014).

After the government in 2007 conducted a policy deemed more cooperative in southern Thailand, the de-escalation effect of violence in the region gradually showed the outcome. Violent incidents decline significantly. Governments, particularly the military, have achieved some success at suppressing insurgency and keeping the peace for some time. However, the implementation of this policy that tends to promote military operations still has not touched the crucial problems in southern Thailand, especially the economic, social development issues. Based on a survey conducted by Prince of Songkla University shows that the most severe difficulties experienced by Thai society in the south are drug abuse, unemployment, rebellion, and poverty (Jitpiromsri, 2014).

\section{CONCLUSION}

Historical facts speak that the ethno-religious conflict in Thailand's southernmost province is not constant; sometimes, they can live peacefully alongside other governments and ethnic groups. Observing the Malay Muslim Patani's insurgency pattern in the Post-Revolution 1932 till now day, Muslim Society only rebelled when regarded as their cultural and religious identity as a threat by the Thai regime (Croissant, 2007).

The previous Thai government's using the aggressive approach to counter-insurgency was thus sacrificing the democratic system and adding to the fertile Malay Muslims Patani insurgency movement. The theme of peace and practical solutions to the problems that cause the emergence 
of insurgency issues in southern Thailand, especially for Malay Muslims Patani is a priority.Experience in Thailand with communist uprisings in the 1970 and the early 1980s show that solutions to the problem of rebellion were to give a fair portion of economic and political fields. In contrast, military solutions were secondary solutions. The insurgency in Malay Muslim Patani as part of the efforts to preserve the traditions and political interests is a part of the most authentic identity for Malay Muslims Patani in southern Thailand that is different from most Thai people, especially the difference In terms of language and religion. The repressive act further encouraged the strong Malay insurgency movement of Patani against the Thai regime, mostly in the last decade.

Considering the political identity model played in pattern of the Malay Muslim Patani insurgency is Islam as a religious political identity. The need of the active role of ASEAN such as Indonesia as a country with largest Muslim population in Southeast Asia, as a sustainable mediator of peace in the Malay Muslims Patani region. 


\section{REFERENCES}

Croissant, A. (2007). Muslim Insurgency, Political Violence, and Democracy in Thailand. Terrorism and Political Violence, 19(1), 1-18. https://doi.org/10.1080/09546550601054485

Engvall, Anders. (2016). Bombs, facts, and myths in southern Thailand. http://www.deepsouthwatch.org/node/9264

Fraser, T. M. (1966). Fishermen of South Thailand: the Malay villagers. New York: Holt, Rinehart and Winston.

Gross, M. L. (2007). A muslim archipelago: Islam and politics in Southeast Asia. Washington D.C.: National Defense Intelligence College.

Jitpiromsri , Srisompob. (2014). An Inconvenient Truth about the Deep South Violent Conflict: A Decade of Chaotic, Constrained Realities and Uncertain Resolution. http://www.deepsouthwatch.org/node/5904

Jory, P. (2007). From "Melayu Patani" to "Thai Muslim": The Spectre of Ethnic Identity in Southern Thailand. SSRN Electronic Journal. https://doi.org/10.2139/ssrn.1317162

LePoer, B. L. (1989). Thailand: a country study (6th ed.). Washington D.C.: Federal Research Division Library of Congress.

Liow, J. C. (2004). The Security Situation in Southern Thailand: Toward an Understanding of Domestic and International Dimensions. Studies in Conflict \& Terrorism, 27(6), 531-548. https://doi.org/10.1080/10576100490513701

Madmarn, H. (1999). The pondok \& Madrasah in Patani. Malaysia : Penerbit Universiti Kebangsaan Malaysia.

Pitsuwan, Surin. (1985). Islam and Malay nationalism : a case study of Malay-Muslims of southern Thailand. Bangkok: Thai Khadi Research Institute, Thammasat University.

Preechasinlapakun, S. (2013). Dynamics and institutionalization of coups in the Thai constitution. Chiba Japan: Institute of Developing Economies Japan External Trade Organization.

Qibtiyah, M. (2019). Tingkah Laku Ekonomi-Politik dalam Hegemoni Agama dan Budaya. Jurnal Studi Sosial Dan Politik, 3(1), 55-68. https://doi.org/https://doi.org/10.19109/jssp.v3i1.4068

Ricklefs, Merle C., Lockhart, B. M., Lau, A., Reyes, P., Aung-Thwin, M., \& Komunitas Bambu. (2013). Sejarah Asia Tenggara : dari masa prasejarah sampai kontemporer (Cetakan pertama.). Jakarta: Komunitas Bambu.

Syukri, Ibrahim.(1985). History of the Malay Kingdom of Patani (Sejarah Kerajaan Melayu Patani). Translated by Conner Bailey and John N. Miksic. Athens, Ohio : Ohio University Center for International Studies. 